\title{
CORRECTLY MEASURING REAL VALUE ADDED
}

\author{
By Shirley Cassing \\ University of Pitsburgh
}

\begin{abstract}
This paper examines issues involved in calculating a value added index in order to measure real value added at the industry level. Three methods of calculating real value added are considered; the Laspeyres double-deflation method recommended by the United Nations System of Nation Accounts, the commonly used single-deflation method, and the double-deflation Divisia method. Actual data are employed to clarify and illustrate the issues involved, and the paper concludes with a recommendation for an appropriate index to use when calculating industry real value added.
\end{abstract}

Real value added is the key to understanding the contribution of the primary inputs, the economies of scale, and technical change in the production process. Historical and contemporary changes in "pure" productivity of an industry can be analyzed by observing real value added data. Industry nominal value added is easy enough to calculate, it is simply the difference between the value of the industry's output and the industry's cost of materials or intermediate inputs. Adjusting nominal value added for price changes in order to calculate real value added is much less straightforward. In defining real value added one encounters index number problems as well as some problems unique to value added itself. This paper investigates issues involved in calculating a real value added index, presents actual data to clarify and illustrate the issues, and concludes with a recommendation for an appropriate index to use when calculating real value added.

The paper is divided into three sections. The first section presents three methods used to calculate real value added indexes. The second section presents and compares the value added series and the corresponding indexes computed with the three methods. Section III concludes the paper.

\section{Value Added Price Index}

Value added is the difference between the value of output and the cost of materials or intermediate inputs. When aggregated over all industries, value added is equal to gross national product and therefore identically equal to gross national expenditure. If one wishes to maintain this fundamental national income accounting identity in real terms as well as in nominal terms, correctly measuring real value added becomes an issue.

Note: This paper has benefitted from the helpful comments of Yahya Jammal and an anonymous referee. The data were provided by the Indonesian Government's Central Bureau of Statistics. 
The concept of real value added is made clearer if a production model is precisely defined. Let output $(q)$ be a function of primary inputs $(k, l)$, intermediate inputs $(x)$, and technology $(t)$, (i.e. $q=f(k, l, x, t)$ ). The real value added index measures the contribution of the intangible inputs (economies of scale and technical change), and the primary inputs (labor and capital) if the marginal products of the intermediate inputs are equivalent to their real prices. The true index of real value added is unique if and only if the primary inputs and technical change are weakly separable from the intermediate inputs in a production function, (i.e. if the production function can be written $q=f(g(k, l, t), x)$ ) and if the production function is subject to constant returns to scale in $g(\cdot)$ and $x$, (Sato, 1976). In measuring real value added one is searching for an estimate of this true index of real value added.

There are two basic approaches to deflating value added. Single deflation directly deflates nominal value added by applying an output price index. Double deflation deflates outputs and inputs separately, each with their own price index. The description that follows considers both approaches and employs various index formulas in calculating real value added.

In national accounts calculating real gross national expenditure is accomplished by employing the Laspeyres formula. For consistency the same method should be used on the production accounts, which is consistent with the Laspeyres double-deflation procedure recommended in the revised United Nations System of National Accounts (UN, 1968). Unfortunately, this method can yield negative figures for real value added when relative price changes are large or when input proportions greatly change due to substitution or technical change. This is especially true when calculating real value added at the industry level. In order to avoid the problems associated with the value added estimates when employing the Laspeyres or UN double-deflation index, many have relied on the singledeflation technique which also has the added advantage of not requiring, the often difficult to obtain, intermediate input prices (David, 1962). The single-deflation method (also called the direct deflation method) uses an output price deflator to deflate both inputs and outputs. Therefore, the single deflated real value added will be positive as long as nominal value added is positive. An obvious weakness of the single-deflation method is its dependence on the extent of sectoral aggregation.

An alternative double deflation method uses the Divisia index formula; this method has received little attention in practice but has many advantages to recommend its use. In particular, the Divisia double deflation index of value added shares the non-negativity property with the single deflation index. Furthermore, since it is a double deflation method it excludes the gains or losses that accrue to the industry due solely to changes in the relative prices of material inputs to outputs, which are a part of the single-deflated value added index. When there are changes in output prices relative to material input prices the single-deflation method will reflect the industry gains or losses due to the relative price changes. For example, if material prices decrease relative to output prices, all else equal, the value of the industry output has increased relative to the cost of materials, and therefore, "terms of trade" have improved for the industry, but the physical productivity of the primary inputs has not changed. The basic idea behind correctly measuring changes in real value added is to separate terms of trade gains 
or losses from changes in physical production so as to permit the measurement of physical productivity of primary inputs.

Also the Divisia double deflation method is free of the distortions in the Laspeyres double deflation value added index. These distortions arise because the Laspeyres value added index measures the level of real value added realized by the optimal set of primary inputs in the current period relative to the base period assuming that the relative prices of materials are always those of the base period. Obviously this method gives the wrong answer. As does a Paasche double deflation index which assumes that relative prices of material are always those of the current period. The true index of value added is bounded by the Laspeyres and Paasche indexes. The true index is unique under the conditions described above and is then correctly measured by the Divisia value added index (Sato, 1976).

The different terms of trade effects that distinguish the single deflation value added index from the Laspeyres double deflation value added index, and the Laspeyres double deflation value added index from the Divisia double deflation value added index are discussed in Hansen and Sato (Hansen, 1974, 1975; Sato, 1976). The Divisia index of value added has much to recommend it; it is free from the problems of the UN (Laspeyres) double-deflation index and it does not depend on the degree of sectoral aggregation like the single-deflation method. 1ts drawback is that it yields a true unique index only when certain conditions are met. This paper contrasts the effects of using these different indexes in calculating real value added for the Indonesian manufacturing sector.

Calculation of the value added indexes is summarized below. Nominal value added in the $i$-th industry at time $t$ is defined as:

$$
v_{i t} V_{i t}=\sum_{j=1}^{N} p_{j t} q_{j t}-\sum_{k=1}^{M} w_{k t} x_{k t}
$$

where $\sum_{j=1}^{N} p_{j t} q_{j t}$ is the total value of the $N$ outputs in the $i$-th industry and $\sum_{k=1}^{M} w_{k r} x_{k t}$ is the cost of the $M$ materials purchased by the $i$-th industry. Prices are represented by $v, p$, and $w$; while the quantities are denoted by $V, q$, and $x$.

The single-deflation method uses an output price index to deflate nominal value added. Real value added for the $i$-th industry $\left(\mathrm{RVA}_{i t}\right)$ is calculated as the difference between nominal output and nominal inputs, each deflated by an output price index. That is:

$$
\mathrm{RVA}_{i t}=\frac{\sum_{k=1}^{N} p_{k \prime} q_{k t}-\sum_{j=1}^{M} w_{j r} x_{j t}}{\mathrm{PO}_{i r}}
$$

where $\mathrm{PO}_{i r}$ is the gross output price index for the $i$-th industry. The gross output price index can be calculated using Laspeyres, Paasche, Divisia, or any other appropriate index formula. In this paper the Törnquist approximation to the Divisia index formula is used. The index form of this single deflation measure is the ratio of $\mathrm{RVA}_{i}$ to $\mathrm{RVA}_{i 0}$, where $\mathrm{RVA}_{i 0}$ is real value added in some base year.

The UN double-deflation method uses separate price indexes for inputs and outputs to deflate nominal valued added. The UN double-deflation value added 
quantity index for industry $i$ is:

$$
\mathrm{UN}_{i t}=\frac{\sum_{j=1}^{N} p_{j 0} q_{j t}-\sum_{k=1}^{M} w_{k 0} x_{k t}}{\sum_{j=1}^{N} p_{j 0} q_{j 0}-\sum_{k=1}^{M} w_{k 0} x_{k 0}}
$$

The implicit Paasche price index for value added can then be easily derived, as the product of the Laspeyres quantity index and the Paasche price index equals the nominal value added ratio for the two periods.

The Divisia index is a continuous time index number formula, and has been widely used in theoretical discussions of data aggregation and measurement of technical change (Diewart, 1987). The Törnqvist approximation replaces the continuous changes with their discrete time counterparts.' The growth rate of the value added quantity in period $t$ relative to period $t-1$ for the discrete approximation to the Divisia formula is:

$$
\begin{aligned}
\ln \frac{V_{i t}}{V_{i t-1}}= & 0.5 \sum_{j=1}^{N}\left(\mu_{j t}+\mu_{j t-1}\right) \ln \left(q_{j t} / q_{j t-1}\right) \\
& -0.5 \sum_{k=1}^{M}\left(\omega_{k t}+\omega_{k t-1}\right) \ln \left(x_{k t} / x_{k t-1}\right),
\end{aligned}
$$

where

$$
\mu_{j t}=\frac{p_{j t} q_{j t}}{v_{i t} V_{i t}} \text { and } \quad \omega_{k t}=\frac{w_{k t} x_{k t}}{v_{i t} V_{i t}} .
$$

The time series of the value added quantity index was then generated using the chain technique (Diewart, 1987). In this paper the Törnqvist approximation to the Divisia index will be used.

It is not unusual to see the single-deffation method employed in practice. Two explanations are offered. One, the UN double-deflation method may give rise to negative real value added figures when relative price changes are large or when input proportions change a great deal due to substitution or technical change. To avoid this problem some investigators have suggested using a singledeflation index. Two, input prices are usually not accessible or easy to obtain, but output prices are generally available. Therefore, the single-deflation index is much easier to compute.

When calculating real value added estimates single-deflated value added indexes, Laspeyres and Divisia double-deflated real value added indexes measure different things. The Divisia double-deflated index represents the pure productivity increases of the primary inputs in an industry, while single-deflated real value added measures pure productivity gains plus the effects of "trading gains." The Laspeyres double-deflation method excludes the trading gains or losses, but includes distortions due to the implicit assumption of a suboptimal use of material inputs. The defects of a Laspeyres index are well-known. Trading gains equal the substitution effect which appear as a change in the marginal productivity of the

\footnotetext{
'Other approximations are feasible. Sims examines chaining the Laspeyres double-deflation index to use as an approximation to the Divisia index (Sims, 1969).
} 
primary inputs due to a change in factor proportions induced by changes in the relative prices of inputs to outputs. For single-deflation real value added, at the economy wide level, imports are the only intermediate inputs, so when they become relatively cheaper, the economy is viewed to be better off with no change in its pure productivity. Obviously, the inclusion or exclusion of the trading gains depends on what one is looking for in real value added. If the pure contribution of primary inputs matters, then exclude trading gains (i.e. use the Divisia value added index). If one is looking to measure economic welfare, then include trading gains (i.e. use single-deflation real value added).

It is interesting to note, though, that correctly measured - that is, by using an "exact" index - real value added cannot be negative as long as nominal value added is non-negative (Sato, 1976). Also, of note is that under certain assumptions when the "true" value added index is unique, it is correctly measured by the Divisia index, and like the cost-of-living index will be bounded by the Paasche and the Laspeyres double-deflation value added indexes. Evidence from others indicates that the Paasche and Laspeyres indexes, unlike the Divisia value added index exhibit poor performance when there are large changes in the relative price of outputs to inputs (Sato, 1976). This poor performance may explain the negative real value added found in earlier studies when employing the Laspeyres index. Since the Divisia value added index is always non-negative, even when the Divisia index is not unique, a very strong case can be made for improving production accounts by adopting the Divisia index. In these days with easy access to highspeed computing calculating the Törnqvist approximation to the Divisia index is a simple matter. The fact that the double-deflation Laspeyres or Paasche index may perform poorly should not be a basis for rejecting real value added as a concept.

\section{Applied Example}

Interesting comparisons suggested by the issues summarized in the paragraphs above show the effects of these various choices. Comparisons of the different indexes are presented for Indonesian Manufacturing Data for large and medium establishments ( 20 or more employees). The data are collected and published by the Indonesian Central Bureau of Statistics. For aggregate manufacturing Figure 1 compares the Törnqvist approximations to the Divisia price index for output, inputs, value added, and the UN double deflation price index (which is the corresponding Paasche pair to the Laspeyres quantity index). Differences in the observed values of the four indexes are very small. However, the effect of using a double-deflation index can be seen by observing the graph. When input and output prices move together, there will be a similar change in the value added index. In this case, double-deflation and single-deflation methods yield similar results. An example of this can be seen in Figure 1 for years 1977 through 1979. When the input price increase is greater than the output price increase the change in the value added price index will be less than the output price change. This occurred in years 1982 through 1984. From 1984 to 1987 output price changes were greater than input price changes and the value added index increase was larger than the output price change. Hereafter, the Törnqvist approximation to 


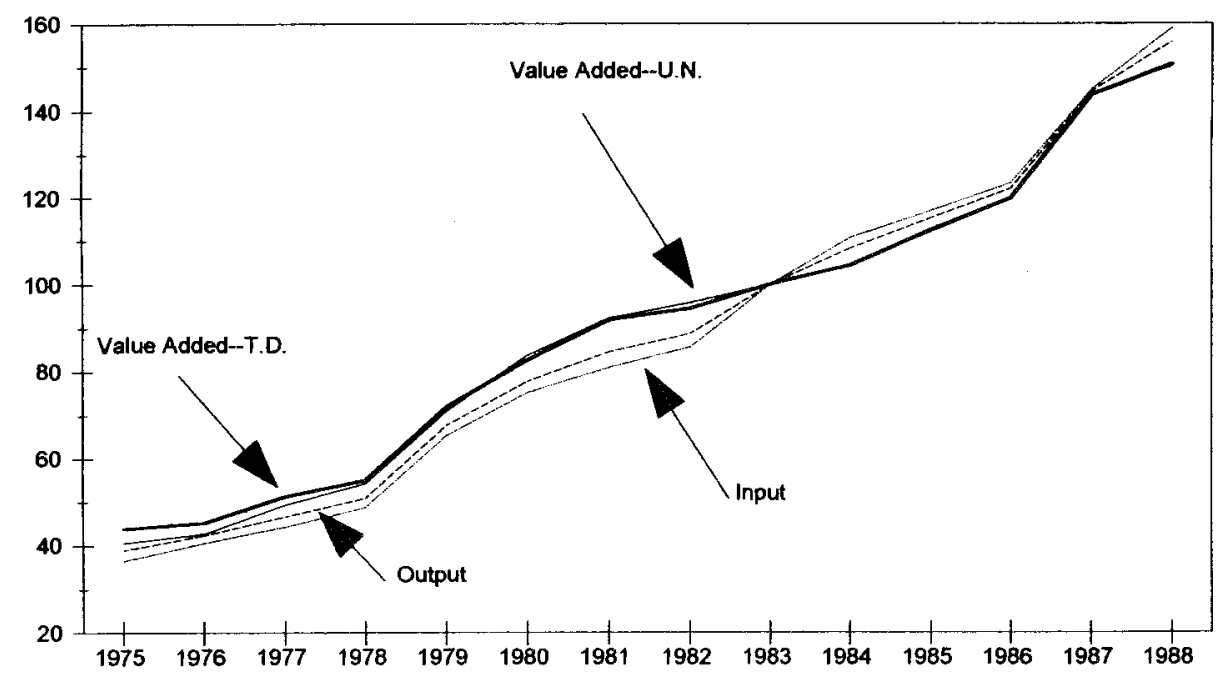

Figure 1. Price Index Comparisons

the Divisia value added quantity index will be referred to as a Törnqvist-Divisia index. In the accompanying graphs it is denoted by the abbreviation T.D.

For the total manufacturing sector two more graphs are reported. Figure 2 shows three different real value added quantity indexes. One is calculated using the single deflation method, the second is calculated using the UN double-deflation technique, and the third is calculated using the Törnqvist-Divisia value added quantity index. In the graph presented it is difficult to distinguish between real value added calculated using the UN method and the Törnqvist-Divisia calculated series. (The UN series is represented with a dotted line, and the Törnqvist-Divisia with a line.) The series derived from a double-deflation method will differ from the series derived from a single-deflation method depending upon the relationship between the input price index and the output price index. When the change in the input price index is greater than the change in the output price index, the growth in real value added (RVA) measured by a double-deflation quantity index will be greater than the change in RVA using a single-deflation quantity index. It is also true, in this case that the change in the double-deflation price index is less than the change in the single-deflation output price index. The period from 1981 to 1988 confirms this observation.

Figure 3 compares the growth rates for the three different RVA series. It shows the absolute value of the differences in growth rates from employing the different indexes-the Törnqvist-Divisia minus the UN growth rate and the Törnqvist-Divisia minus the output growth rate. When the input price index and the output price index differ a more pronounced difference in the single-deflation vs. double-deflation growth rates is observed. For example, note what happens from 1985 to 1988 . In Figure 1 we see that the input and output price indexes increased at about the same rate from 1981 to 1982 and from 1985 to 1986, and in Figures 2 and 3 that the RVA growth during those years was similar for all series. From 1987 to 1988 the input price index increased relative to the output 


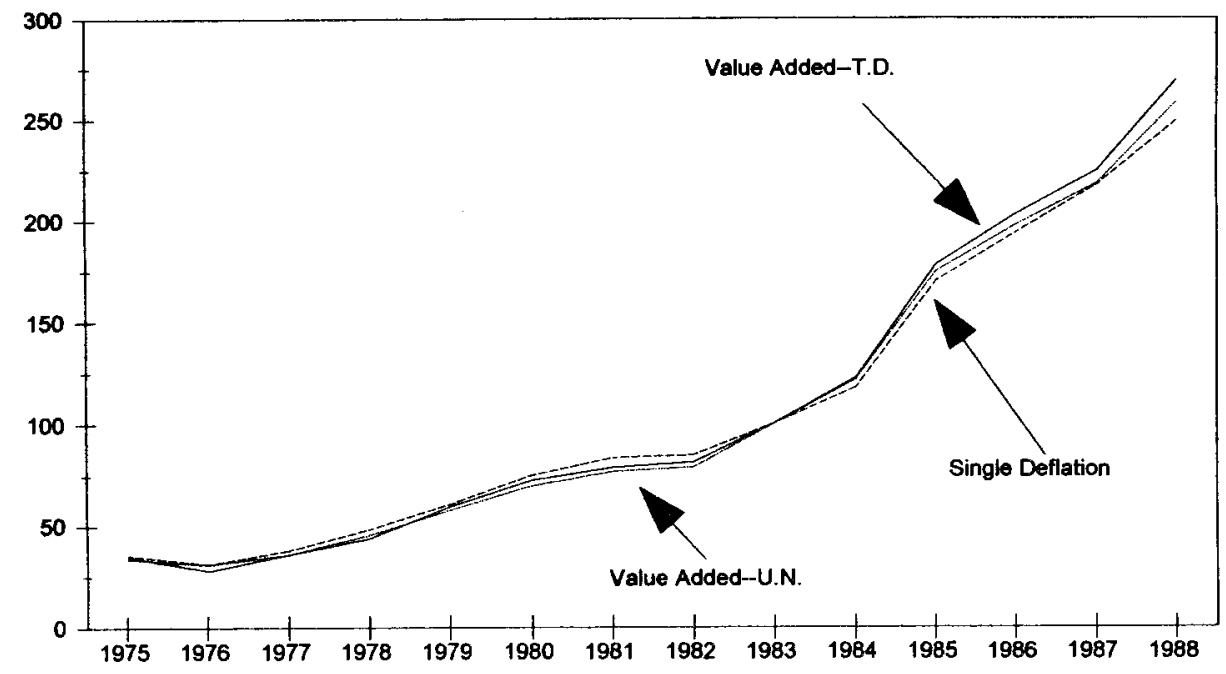

Figure 2. Quantity Index Comparisons

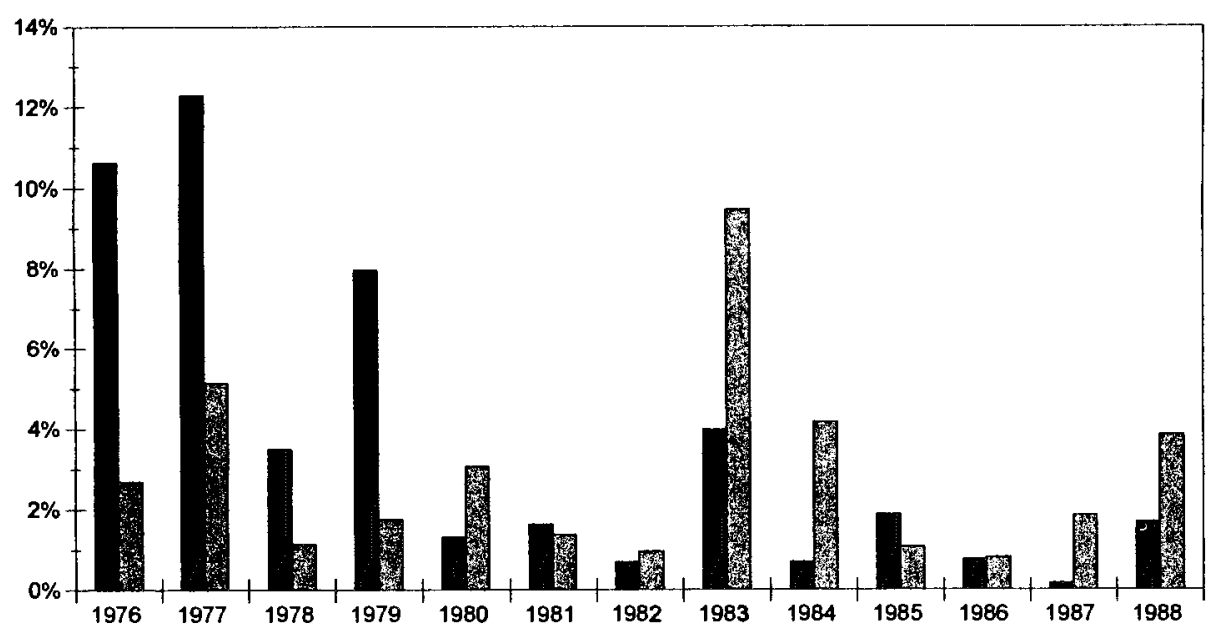

T.D.-U.N. T.D.-Single Deflation

Figure 3. Growth Rate Differences

price index, thus the UN double-deflation price index and the Törnquist-Divisia price index increased less than the output price index; and RVA calculated using these double deflation quantity indexes showed a higher growth rate. In some of the earlier years we observe the opposite occurring.

Differences in real value added using double-deflation methods instead of single-deflation methods are more striking the less aggregated is the data. Within an industry it is more likely for one to observe dissimilarities in the movements 
of input and output prices than in the aggregate. Therefore, one would expect to observe greater differences in RVA calculated using the double-deflation methods than RVA using the single-deflation method. We anticipate that the industry level results will mirror the aggregate results, but show more disparity when employing the different methods.

Only two of the nine two digit ISIC level industries are presented. Industry 31-Food and Food Products-and Industry 32-Textiles-are representative of the other industry results. For years 1985 to 1988 , the rate of change in the input price index for the aggregate manufacturing sector and for all sectors except two (Wood and Textiles) was usually greater than the rate of change in the output price index, and therefore, growth of RVA calculated using either the UN doubledeflation price index or the Törnqvist-Divisia price index was higher than growth calculated using the output price index.

Graphs similar to the aggregate manufacturing sector graphs are provided for Industries 31 and 32 in order to investigate further the two digit level results. By comparing Figures 4 and 5 with Figure 1 and Figures 6 and 7 with Figure 2 we see the anticipated results-the greater differences in the indexes are greater at the industry level than at the aggregate level. Looking closely at Figures 2, 6, and 7, we see similarities between Industry 31 (Food Products, Figure 6) and the aggregate (Figure 2); since 1983 RVA computed using the two double-deflation value added indexes are greater than single-deflation RVA. Whereas in Industry 32 (Textiles, Figure 7) the opposite occurred, and RVA using the T.D. and UN value added quantity indexes actually declined in 1987, while the single-deflation index continued to show positive growth. This occurred because output prices showed a substantial increase relative to input prices in that year, resulting in a

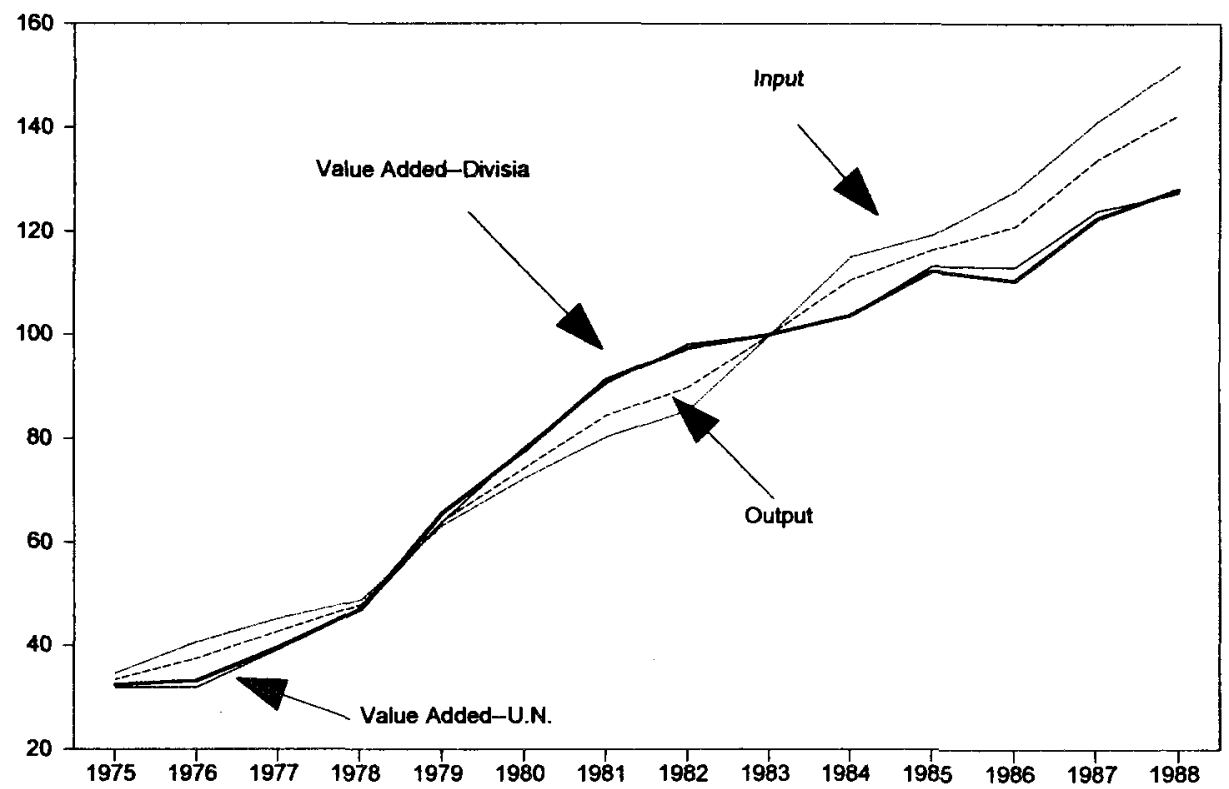

Figure 4. Price Index Comparisons - Food Products 


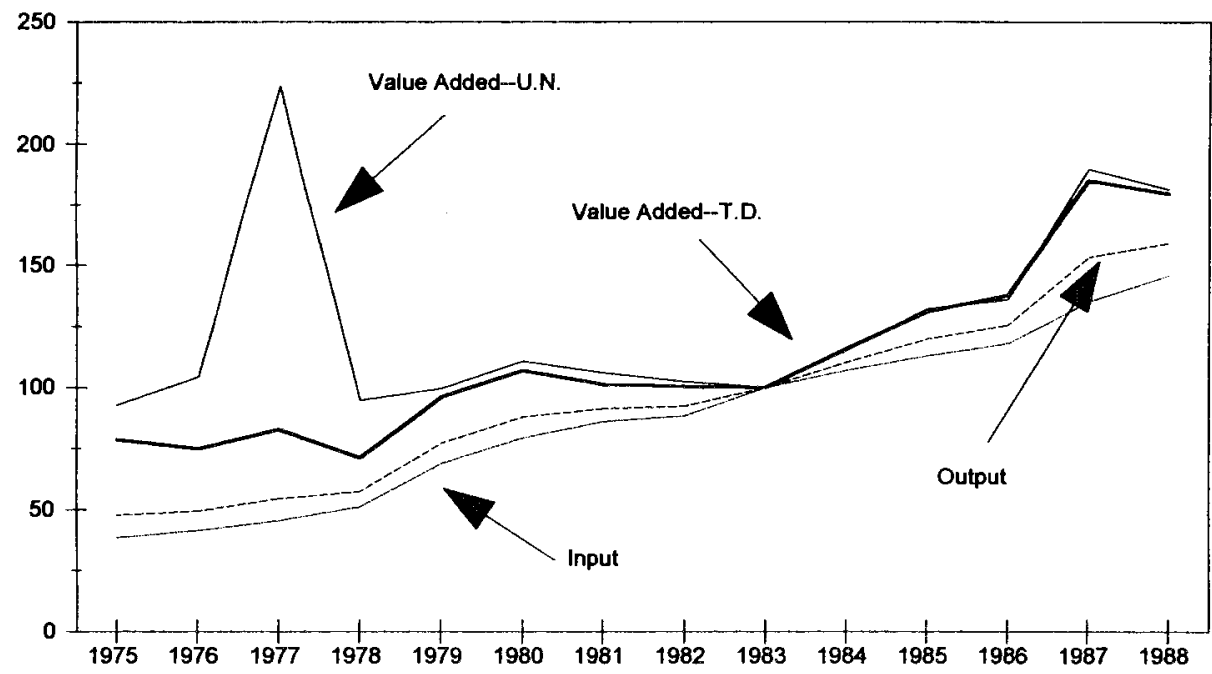

Figure 5. Price Index Comparisons-Textiles

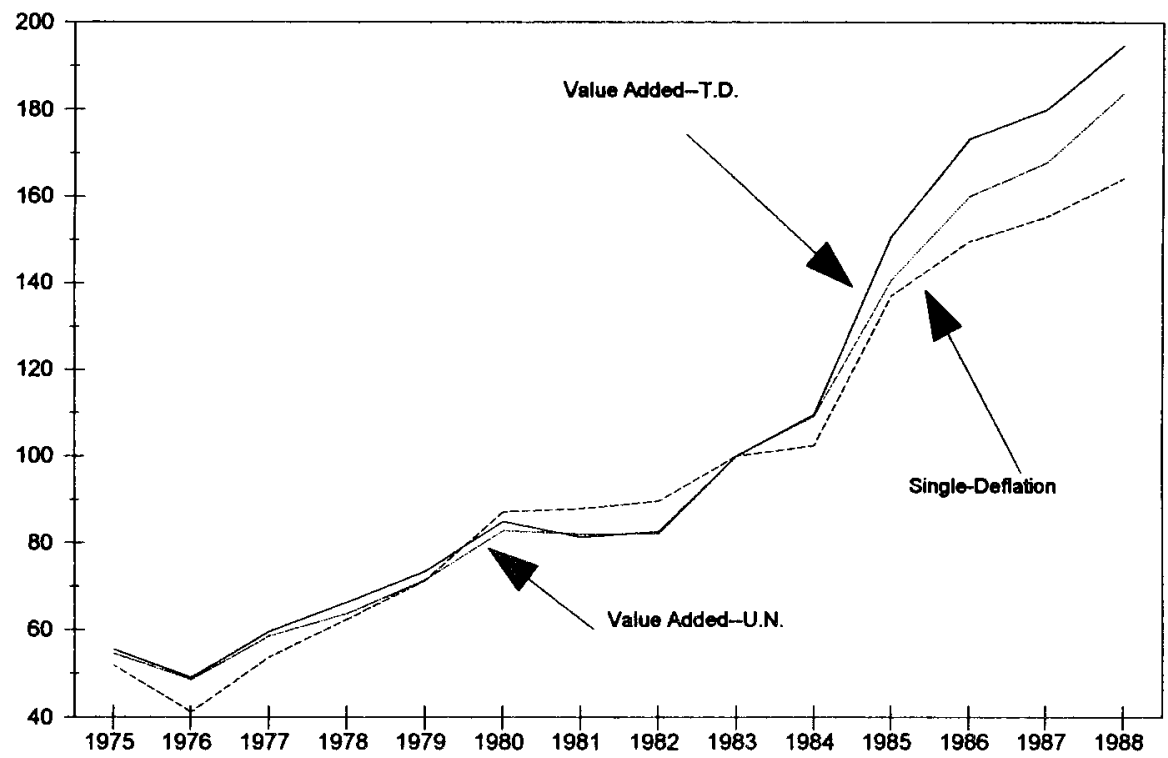

Figure 6. Quantity Index Comparisons-.-Food Products

very large increase in the UN double-deflation and Törnqvist-Divisia value added price indexes. The increase was large enough, in fact, to result in a decline in the corresponding real value added quantity indexes.

Figures 8, 9, and 10 show how the different indexes affect the calculated growth rate of the industry level RVA series. (Figure 10 is the same as Figure 9 except that the first four years are eliminated because the changes in 1977 and 1978 were unusually large. This will be discussed later.) Note that the industry 


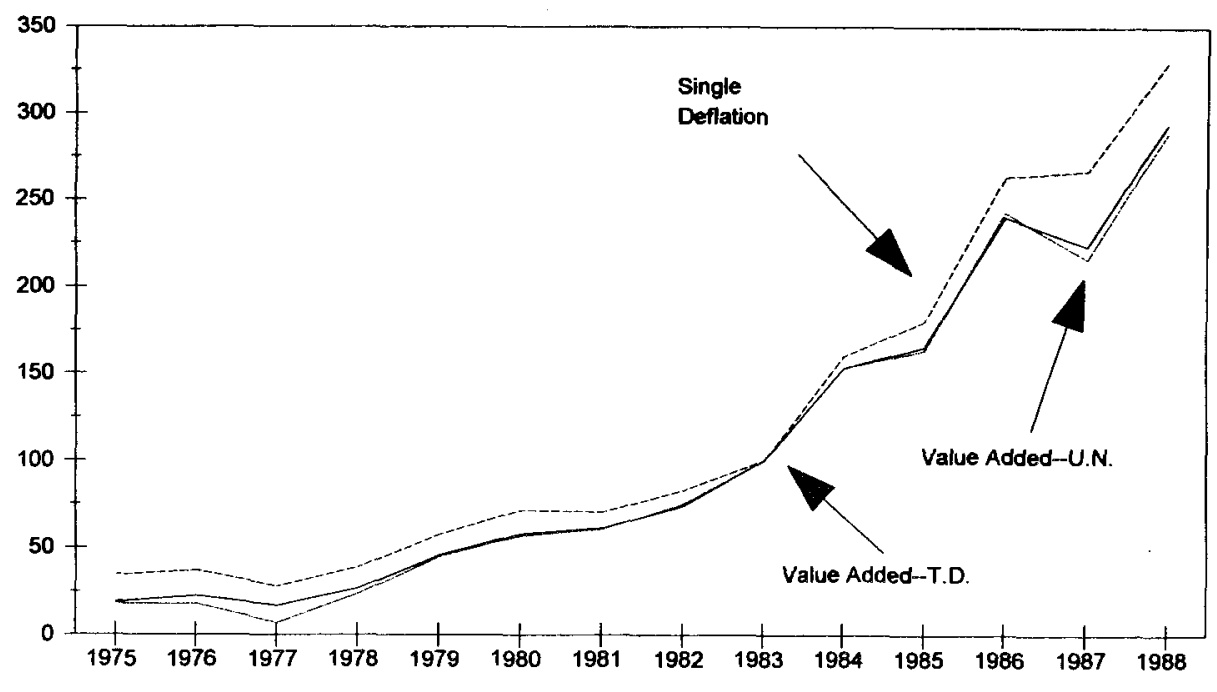

Figure 7. Quantity Index Comparisons-Textiles

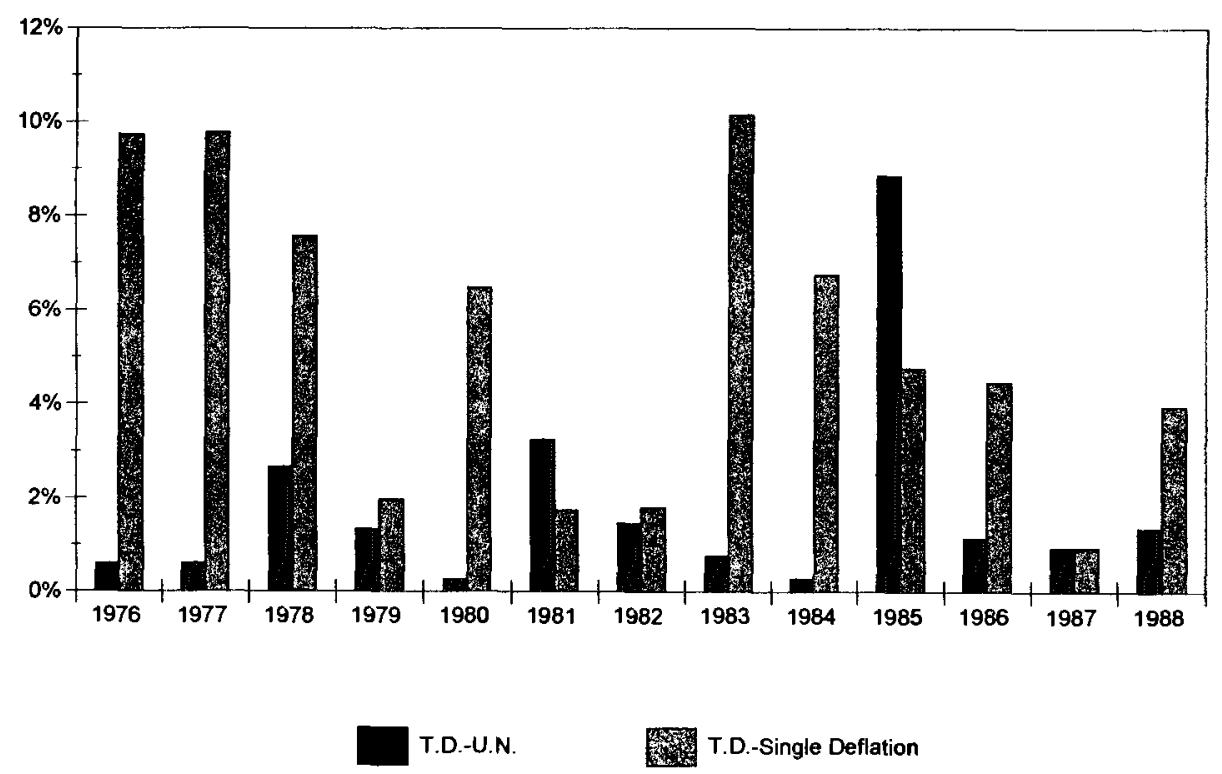

Figure 8. Growth Rate Differences-Food Products

differences are greater than the differences reported for the aggregate manufacturing sector in Figure 3. In fact, the mean absolute difference for the TörnquistDivisia--UN comparison was 0.51 percent for the aggregate series, 0.7 percent for Industry 31, and 15.9 percent for Industry 32. The mean absolute difference for the Törnquist-Divisia-Output Index comparison was 2.7 percent for the aggregate series, 4.5 percent for Industry 31 , and 7.5 percent for Industry 32 . Also 


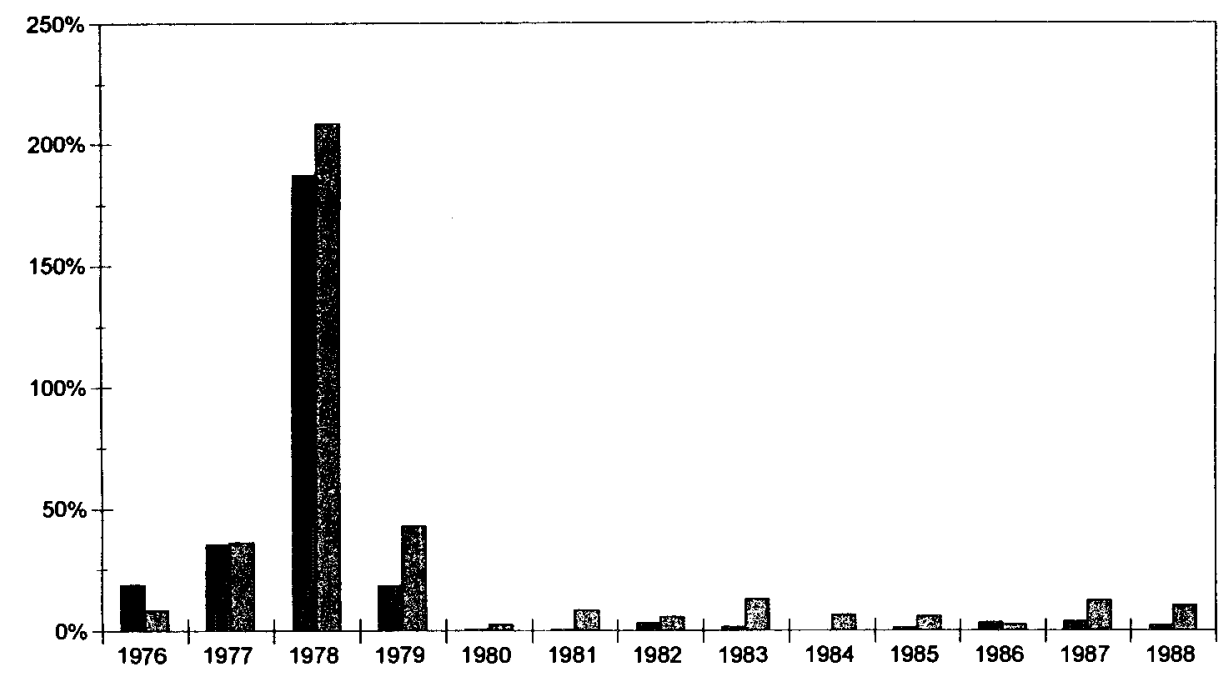

T.D.-U.N. T.D.-Single Deflation

Figure 9. Growth Rate Differences-Textiles

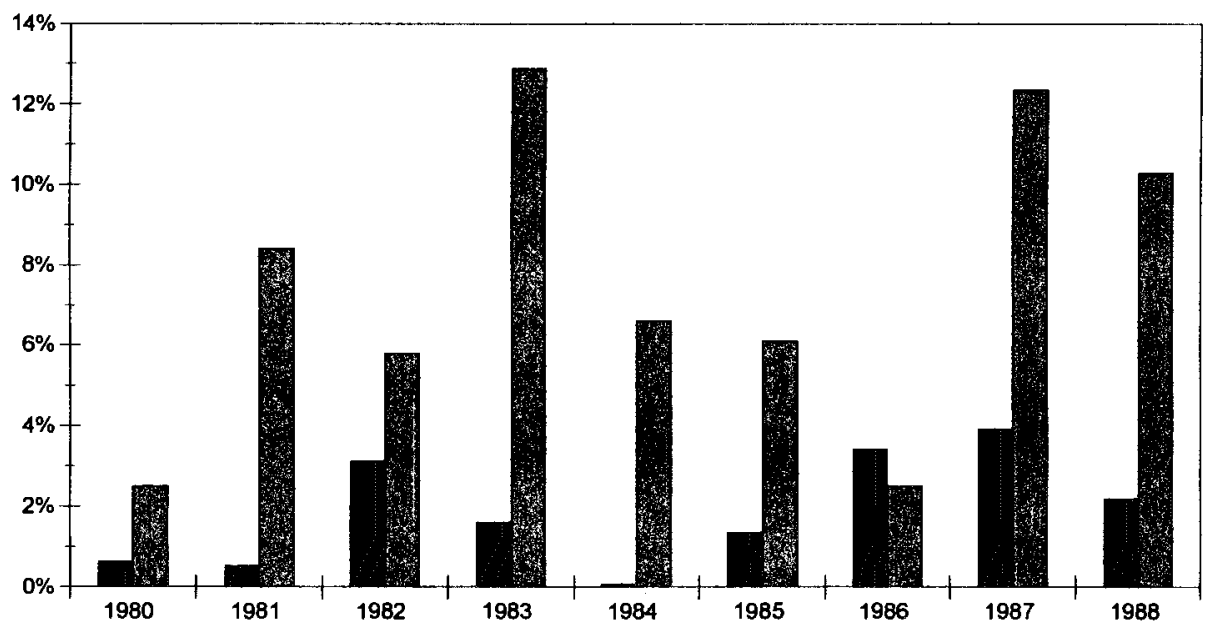

T.D.-U.N. T.D.-Single Deflation

Figure 10. Growth Rate Differences--Textiles

interesting are the large observed differences in the RVA growth rates for the UN double-deflation method and the Törnqvist-Divisia method for Industry 32.

Figures 5, 7, and 9 present results for the textiles industry. The striking change in the UN value added price index in Figure 5 can be explained by a large change in the input proportions during the years 1975 to 1979. Such a large increase in 
the index can lead to a large decline in real value added. This example highlights the problems associated with the UN double-deflation as discussed above. It also shows that the Törnquist-Divisia method is free from the erratic changes observed in the UN method, thus reinforcing the notion that real value added is a valid concept as long as it is correctly calculated.

\section{Conclusions}

This paper demonstrates the effects of using the Törnqvist-Divisia value added price index for the Indonesian manufacturing sector. The results support what is already known. Applying the UN double-deflation method or the Tönquist-Divisia method in calculating real value added rather than the singledeflation method does not make a big difference when output and input deflators move in a very similar fashion, and this will be more likely the greater the degree of aggregation. For the whole economy, all domestic input prices for one sector are output prices for another sector, and these should move together, especially after a one year adjustment lag. However, individual sectors are more likely to have dissimilarities in the movements of input and output prices, and therefore, have greater differences between indexes calculated using the different methods. The relationships between the output, input, UN and T.D. price indexes can be seen in Figure 1 for aggregate manufacturing and in Figures 4 and 5 for manufacturing at the two digit level. As expected, the movements in the indexes for the aggregate sector are more similar than the movements in the price indexes for the two digit sectors. Consequently, there are greater differences between the quantity indexes calculated using the three different methods for the individual manufacturing sectors than for aggregate manufacturing. This can be seen by comparing the aggregate series in Figure 2 with the individual sectors in Figures 6 and 7.

\section{REFERENCES}

David, P. A., The Deflation of Value Added, Review of Economics and Statistics, 44, 148-155, May, 1962.

Diewart, W. E., Index Numbers, in Eatwell, J., Milgate, M., and Newman, P. (eds.), The New Palgrave: A Dictionary of Economics, Stockton Press, New York, 1987.

Hansen, B., A Proposed Real Net Output Index: A Comment, Review of Economics and Statistics, 56, 415-416, August, 1974.

- Double Deflation and the Value Added Product : Comment, Review of Economics and Statistics, 57, 382-383, August, 1975.

Jones, L. P., Indexing, Economic Analysis and Real Manufacturing Growth, Development Studies Project research paper \# 90, August, 1989.

Sato, K., The Meaning and Measurement of the Real Value Added Index, Review of Economics and Statistics, 58, 434-442, November, 1976.

Sims, C. A., Theoretical Basis for a Double Deflated Index of Real Value Added, Review of Econontics and Statistics, 51, 470-471, November, 1969.

United Nations, A System of National Accounts, Studies in Methods Series F, No. 2, Rev. 3, New York, 1968. 